\title{
Symptoms associated with different degrees of megaesophagus in Chagas disease
}

\author{
Jaline de Araujo OLIVEIRA ${ }^{1}$, Aretuza Zaupa Gasparim EI GHARIB ${ }^{1}$ and Roberto Oliveira DANTAS $^{2}$
}

Received: 16 April 2021 Accepted: 15 June 2021

\begin{abstract}
Background - Dysphagia is the most frequent digestive symptom in Chagas disease, although other symptoms are reported. These symptoms can be associated with the degree of radiological impairment of the esophagus and the duration of dysphagia. Objective - This investigation aimed to assess the symptoms and the time of dysphagia related to the different degrees of megaesophagus in patients with Chagas disease. Methods - A total of 29 patients aged 48 to 73 years participated in this investigation. All of them had dysphagia and a positive serum result for Chagas disease. They were submitted to the assessment of symptoms and radiological examination of the esophagus to assess the degree of megaesophagus, which ranged from I (mild change) to IV (intense change). Dysphagia was quantified with the Eating Assessment Tool (EAT-10). Results - Twelve (41\%) patients had megaesophagus degree I, 9 (31\%) had degree II, and 8 (28\%) had degrees III (6) and IV (2). The intensity of dysphagia was not related to the result of the radiological examination, with EAT-10 median of 5.5 for the degree I, 9.0 for degree II, and 5.5 for degrees III and IV ( $P>0.25)$. Choking $(14 \%)$, regurgitation $(21 \%)$, voice complaint $(21 \%)$, weight loss (17\%), and odynophagia (17\%) were not related to the degree of megaesophagus. Voice changes and odynophagia were related to the patients' time of dysphagia. Likewise, the frequency of symptoms and EAT-10 values were related to the duration of dysphagia. Conclusion - The longer the patient had dysphagia, the more frequent were the symptoms reported by the patients. There was no relationship between the degrees of megaesophagus and the symptoms and intensity of dysphagia.
\end{abstract}

Keywords - Chagas disease; esophageal achalasia; deglutition disorders; esophageal disorders; trypanosomiasis.

\section{INTRODUCTION}

Chagas disease, caused by the flagellate protozoan Trypanosoma cruzi, is an infectious condition with great morbimortality potential and impact on the biological, social, economic, and psychological aspects of health ${ }^{(1)}$. It is widely distributed in Latin America and present in other continents, as well ${ }^{(1,2)}$.

In the chronic and symptomatic phase of the disease, the heart and digestive system suffer significant clinical impairment ${ }^{(1,3)}$. In the digestive system, esophagopathy causes the most frequent clinical manifestations, a result of the destruction of the myenteric plexus of the esophagus. It triggers functional motility changes, such as hypocontractility, loss of peristalsis, achalasia of the lower esophageal sphincter, and megaesophagus ${ }^{(4,5)}$. Esophageal motility disorder causes dysphagia and possible regurgitation of the swallowed material, heartburn, and weight loss ${ }^{(4,5)}$.

Dysphagia, which means swallowing difficulty, is the most frequent digestive symptom, occurring during ingestion of both solid and liquid foods - though most often and intense with solid foods ${ }^{(4)}$. The patient most often manifests the perception of the difficult transit of the bolus through the retrosternal area, yet the difficulty can be perceived in a more proximal location.

Despite the expected relationship between the degree of megaesophagus and dysphagia - in which the greater the intensity of dysphagia perceived by the patient, the greater the radiological impairment of the esophagus -, patients with significant dilation of the esophagus may report discrete dysphagia. It can be either oropharyngeal or esophageal, as changes in the esophagus, pharyngoesophageal transit, and pharynx are observed in the disease $\mathrm{e}^{(4-8)}$.

The objective of this investigation was to relate dysphagia and other symptoms to the different degrees of megaesophagus in Chagas disease, as well as the time since the patient first perceived they had dysphagia. The hypothesis is that patients whose esophagus is most impaired according to radiological examination and whose dysphagia has lasted longer have more intense dysphagia and more frequent symptoms.

\section{METHODS}

This research was approved by the Human Research Ethics Committee of the University of Maringá (UEM) under Certificate of Presentation for Ethical Consideration (CAAE) number 45350415.0.0000.0104. All participating patients signed the Informed Consent Form (ICF).

This is an observational, non-intervention investigation. The data were collected at UEM, while the radiological examinations were conducted at a radiology clinic in the city of Maringá (Paraná). Chagas disease patients (positive serum result) of both sexes with radiological change in the esophagus and self-reported dysphagia for at least one year were included. Patients with a negative serum result for Trypanosoma cruzi infection, with a history of neurological and/or oncological changes, without dysphagia, or submitted to surgical or endoscopic treatment were not included.

Declared conflict of interest of all authors: none

Disclosure of funding: no funding received

${ }^{1}$ Universidade Estadual de Maringá, Maringá, PR, Brasil. ${ }^{2}$ Faculdade de Medicina de Ribeirão Preto, Universidade de São Paulo, Ribeirão Preto, SP, Brasil.

Corresponding author: Roberto Oliveira Dantas. E-mail: rodantas@fmrp.usp.br 
It was investigated whether the patients had symptoms other than dysphagia, and for how long they had had dysphagia. The Eating Assessment Tool (EAT-10) ${ }^{(9)}$ translated and validated into Portuguese ${ }^{(10)}$ was used to assess dysphagia. All the patients had EAT-10 results $\geq 3$, which indicates dysphagia according to what has been established in this protocol ${ }^{(9,10)}$.

Radiological examinations of the esophagus were conducted to classify megaesophagus into four degrees based on the technique described in $1960^{(11)}$, in which degree $\mathrm{I}$ is the least impaired and degree IV, the most impaired ${ }^{(11-13)}$. The descriptions of these degrees are in reference ${ }^{(13)}$. The diagnosis of esophageal involvement by Chagas' disease was done by the radiologic examination.

The data obtained were entered into a Microsoft Excel 2013 spreadsheet and statistically analyzed with Statistical Single User, version 13.2. The chi-square test was used for the statistical analysis, and the multiple quartile regression model, for the EAT-10 assessment $^{(14)}$. Comparisons with $P \leq 0.05$ were considered significant.

\section{RESULTS}

Altogether, 29 individuals participated in the study - $21(72 \%)$ females and $8(28 \%)$ males, aged 48 to 73 years, mean $63 \pm 5$ years. Twelve $(41 \%)$ patients had megaesophagus degree I, $9(31 \%)$ had degree II, and $8(28 \%)$ had either degree III or IV (six with degree III and two with degree IV).

The EAT-10 results related to the degree of megaesophagus are shown in TABLE 1, and the frequency of symptoms in relation to the degree of megaesophagus is shown in TABLE 2. There was no relationship between the quantitative assessment of dysphagia (EAT$10)$ and the degree of megaesophagus $(P>0.25)$, nor between the frequency of symptoms and the degree of megaesophagus $(P=0.55)$.

TABLE 1. Results of the Eating Assessment Tool (EAT-10) related to the degree of megaesophagus in patients with Chagas disease.

\begin{tabular}{lccc}
\hline & 1st quartile & Median & 3rd quartile \\
\hline Degree I $(\mathrm{N}=12)$ & 3.0 & 5.5 & 10.0 \\
Degree II $(\mathrm{N}=9)$ & 8.0 & 9.0 & 11.5 \\
Degrees III/IV $(\mathrm{N}=8)$ & 4.5 & 5.5 & 13.5 \\
\hline
\end{tabular}

$P>0.25$. N: number.

TABLE 2. Frequency of the symptoms in relation to the degree of megaesophagus.

\begin{tabular}{|c|c|c|c|c|c|c|c|c|}
\hline \multirow{4}{*}{ Symptoms } & \multicolumn{8}{|c|}{ Degree of megaesophagus } \\
\hline & \multirow{2}{*}{\multicolumn{2}{|c|}{$\begin{array}{c}\text { Degree } \\
\mathbf{I} \\
\mathrm{N}=12\end{array}$}} & \multirow{2}{*}{\multicolumn{2}{|c|}{$\begin{array}{c}\text { Degree } \\
\text { II } \\
\mathrm{N}=9\end{array}$}} & \multirow{2}{*}{\multicolumn{2}{|c|}{$\begin{array}{c}\text { Degrees } \\
\text { III/IV } \\
\mathrm{N}=8\end{array}$}} & \multirow{2}{*}{\multicolumn{2}{|c|}{$\begin{array}{l}\text { Total } \\
\mathrm{N}=29\end{array}$}} \\
\hline & & & & & & & & \\
\hline & $\mathbf{N}$ & $\%$ & $\mathbf{N}$ & $\%$ & $\mathbf{N}$ & $\%$ & $\mathbf{N}$ & $\%$ \\
\hline Coughing & 1 & 8 & 0 & 0 & 0 & 0 & 1 & 3 \\
\hline Choking & 1 & 8 & 1 & 11 & 2 & 25 & 4 & 14 \\
\hline Voice complaint & 3 & 25 & 2 & 22 & 1 & 13 & 6 & 21 \\
\hline Regurgitation & 2 & 16 & 0 & 0 & 4 & 50 & 6 & 21 \\
\hline Odynophagia & 3 & 25 & 2 & 22 & 0 & 0 & 5 & 17 \\
\hline Weight loss & 2 & 16 & 2 & 22 & 1 & 13 & 5 & 17 \\
\hline $\begin{array}{l}\text { Food stuck in } \\
\text { the throat }\end{array}$ & 0 & 0 & 1 & 11 & 0 & 0 & 1 & 3 \\
\hline Vomit & 0 & 0 & 1 & 11 & 0 & 0 & 1 & 3 \\
\hline
\end{tabular}

$P=0.55$ (chi-square test). N: number.
Furthermore, there was no relationship between the time of dysphagia and the degree of megaesophagus ( $P=0.87$, TABLE 3 ). On the other hand, there was a relationship between time of dysphagia and EAT-10 $(P=0.02$, TABLE 4$)$, with a tendency of higher EAT-10 scores occurring in patients whose dysphagia had been lasting for longer. The EAT-10 median was 5.0 (limits 3 to 11) in patients with dysphagia for one to ten years and 13.5 (limits 4 to 26) in patients with dysphagia for more than ten years $(P<0.05)$. There was a relationship between the time the patient had had dysphagia and the frequency of the symptoms - the longer the dysphagia had been lasting, the more frequent the symptoms ( $P=0.02$, TABLE 5).

TABLE 3. Time of dysphagia, in years, in patients with Chagas disease in relation to the degree of megaesophagus, expressed in number $(\mathrm{N})$ and percentage $(\%)$ of patients.

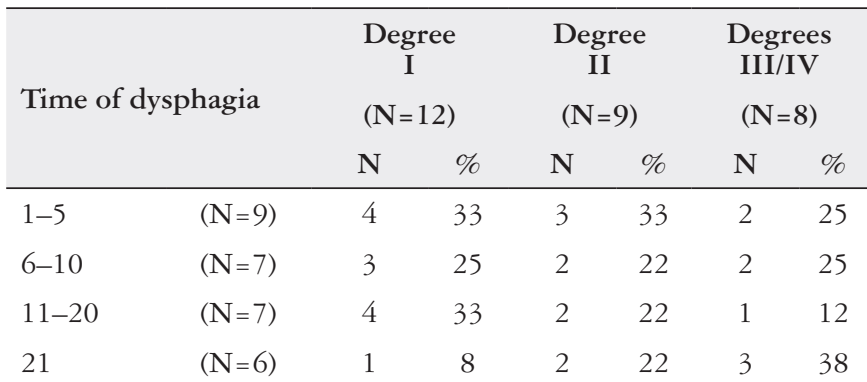

$P=0.87 . \mathrm{N}$ : number.

TABLE 4. Time of dysphagia, in years, in patients with Chagas disease in relation to the results of the Eating Assessment Tool (EAT-10).

\begin{tabular}{lcccc}
\hline \multirow{2}{*}{ Time of dysphagia } & \multicolumn{3}{c}{ EAT-10 } \\
\cline { 3 - 5 } & $(\mathrm{N}=9)$ & 2.5 & 3.0 & 3.5 \\
\hline $1-5$ & $(\mathrm{~N}=7)$ & 5.0 & 8.0 & 10.0 \\
$6-10$ & $(\mathrm{~N}=7)$ & 5.0 & 15.0 & 22.0 \\
$11-20$ & $(\mathrm{~N}=6)$ & 10.0 & 13.5 & 17.0 \\
21 &
\end{tabular}

EAT-10: Eating Assessment Tool; $P=0.02 .1-5$ years vs $>20$ years. $\mathrm{N}$ : number.

TABLE 5. Frequency of the symptoms of the patients with Chagas disease in relation to the time of dysphagia, in years.

\begin{tabular}{|c|c|c|c|c|c|c|c|c|}
\hline \multirow{3}{*}{ Symptoms } & \multicolumn{8}{|c|}{ Time of dysphagia (years) } \\
\hline & \multicolumn{2}{|c|}{$\begin{array}{c}1-5 \\
(\mathrm{~N}=9)\end{array}$} & \multicolumn{2}{|c|}{$\begin{array}{l}6-10 \\
(N=7)\end{array}$} & \multicolumn{2}{|c|}{$\begin{array}{l}11-20 \\
(N=7)\end{array}$} & \multicolumn{2}{|c|}{$\begin{array}{c}>20 \\
(\mathrm{~N}=6)\end{array}$} \\
\hline & $\mathbf{N}$ & $\%$ & $\mathbf{N}$ & $\%$ & $\mathbf{N}$ & $\%$ & $\mathbf{N}$ & $\%$ \\
\hline Coughing & 0 & 0 & 1 & 14 & 0 & 0 & 0 & 0 \\
\hline Choking & 0 & 0 & 2 & 29 & 0 & 0 & 2 & 33 \\
\hline Voice complaint & 1 & 11 & 2 & 29 & 3 & 43 & 0 & 0 \\
\hline Regurgitation & 3 & 33 & 0 & 0 & 0 & 0 & 3 & 50 \\
\hline Odynophagia & 1 & 11 & 0 & 0 & 4 & 57 & 0 & 0 \\
\hline Weight loss & 3 & 3 & 2 & 29 & 0 & 0 & 0 & 0 \\
\hline $\begin{array}{l}\text { Food stuck in } \\
\text { the throat }\end{array}$ & 1 & 11 & 0 & 0 & 0 & 0 & 0 & 0 \\
\hline Vomit & 1 & 11 & 0 & 0 & 0 & 0 & 1 & 3 \\
\hline
\end{tabular}

$P=0.02 . \mathrm{N}:$ number 


\section{DISCUSSION}

Of the patients infected with Trypanosoma cruzi, $7 \%$ to $10 \%$ develop motor changes in the esophagus in the chronic phase i.e., simultaneous and ineffective contractions of the body of the esophagus and partial or absent relaxation of the lower esophageal sphincter (achalasia) ${ }^{(4)}$. They cause various symptoms, mainly dysphagia, but also regurgitation, chest pain, and heartburn.

In this study, $12(41 \%)$ out of the patients assessed had megaesophagus degree I, $9(31 \%)$ had degree II, and $8(28 \%)$ had either degree III or IV. We assumed that the longer the dysphagia had been lasting, the more intense the radiological impairment of the esophagus would be. This hypothesis did not prove to be true, as it had been suggested in a previous paper ${ }^{(15)}$. This indicates that the esophageal impairment caused by the disease occurs mainly in the acute phase, with little or no evolution in the esophageal changes in most of the patients, which must be a consequence of the cellular and humoral response to the Trypanosoma cruzi. The association between the loss of neurons in the myenteric plexus caused by Chagas disease and the loss caused by aging ${ }^{(16)}$ can explain both the onset of dysphagia many years after the patient was infected with $T$. cruzi and the greater intensity of dysphagia years after the symptoms appeared. However, a paper with a larger number of Chagas disease patients did not found relationship between age and radiological grade, and described a relation between dysphagia and the degree of megaesophagus ${ }^{(13)}$.

The most reported symptoms associated with dysphagia were voice complaint (in $21 \%$ of the patients assessed), regurgitation $(21 \%)$, odynophagia $(17 \%)$, weight loss $(17 \%)$, and choking $(14 \%)$. The most frequent voice alteration was hoarseness. Previous paper describe the occurrence of multiple swallowings (14\%), coughing $(18 \%)$, phlegm $(9 \%)$, hoarseness $(36 \%)$ and, in the videofluoroscopy, pharyngeal residues $(18 \%)$ and laryngeal penetration $(18 \%)^{(8)}$. In a paper including patients without megaesophagus, the described symptoms, besides dysphagia, were heartburn (40\%), regurgitation $(6 \%)$, odynophagia $(4 \%)$, retrosternal pain $(12 \%)$, and coughing $(6 \%)^{(17)}$.

In patients with dysphagia onset over 20 years before, the symptoms were reportedly more frequent. Regurgitation usually appears later than dysphagia and occurs either after ingesting foods or when the patient lies down. It is more frequent when the diameter of the esophagus is increased (megaesophagus degrees III and IV) ${ }^{(13)}$, potentially causing aspiration bronchopneumonia. A modern assessment method revealed that $78 \%$ of the patients with megaesophagus due to Chagas disease have aspiration of esophageal content into the airways ${ }^{(18)}$.
The overall analysis of the results revealed no statistically significant data in the association between symptomatology and degree of megaesophagus. However, it has been described that patients with the increased diameter of the esophagus lose weight more frequently than those whose esophagus is not increased in diameter ${ }^{(13,19)}$. The cultural diversity of the patients influences the manifestation of symptoms ${ }^{(20)}$. Hence, patients with greater impairment in motility and esophageal transit may have fewer complaints than patients with little functional change in the esophagus. Previous publication evaluated the symptoms of Chagas disease megaesophagus in 500 consecutive prospective patients and found dysphagia $(97 \%)$, regurgitation $(65 \%)$, retroesternal pain $(59 \%)$, odinophagia $(56 \%)$ and heartburn (32\%) as the symptoms ${ }^{(13)}$. Different of the present investigation there was more intense dysphagia, more frequent chest pain, odynophagia and weight loss in patients with a more intense degree of megaesophagus, and a relation between degree of megaesophagus and time of dysphagia. Different populations and the number of patients included may be the cause of the contradictory results. However, the method of evaluation of dysphagia should be the most important factor that explain the difference, once EAT-10 evaluated dysphagia by the patients perspective.

EAT-10 is a quantitative method to characterize dysphagia by the patients, that has been validated and used in many countries around the world and whose score ranges from 0 to 40 - the higher the score, the more intense the dysphagia in the patient's perception $^{(21)}$.

This investigation has limitations. The number of cases studied was not large, though enough to come to conclusions. The patients' age may have influenced the results, although the effects of aging on swallowing occur more intensely after 70 years old ${ }^{(22)}$.

In conclusion, we found no relationship between the degree of megaesophagus and the frequency of manifestations associated with swallowing in Chagas disease. The time of dysphagia was related to the symptoms - the longer the time of dysphagia, the more frequent the symptoms and the intensity of dysphagia perceived by the patients.

\section{Authors' contribution}

Oliveira JA, Gharib AZGE, and Dantas RO: participated in the project, data acquisition, discussion of the results, writing of the manuscript, and decision to submit for publication.

\section{Orcid}

Jaline A Oliveira: 0000-0002-2056-1716.

Aretuza Z G El Gharib: 0000-0001-6183-2204.

Roberto O Dantas: 0000-0003-2183-0815. 
Oliveira JA, Gharib AZGE, Dantas RO. Sintomas associados aos diferentes graus de megaesôfago na doença de Chagas. Arq Gastroenterol. 2021;58(4):491-4.

RESUMO - Contexto - Disfagia é o mais frequente sintoma digestivo da doença de Chagas; entretanto, outros sintomas podem ser referidos. Esses sintomas podem ser associados ao grau de comprometimento radiológico do esôfago e à duração da disfagia. Objetivo - Avaliar os sintomas e o tempo de disfagia relacionados com os diferentes graus de megaesôfago em pacientes com doença de Chagas. Métodos - Participaram da investigação 29 pacientes com idades entre 48 e 73 anos, todos com disfagia e teste sorológico positivo para doença de Chagas. Eles foram submetidos à avaliação de sintomas e exame radiológico do esôfago para avaliar o grau de megaesôfago, que variou de I (alteração discreta) a IV (alteração intensa). Disfagia foi quantificada pelo método Eating Assessment Tool (EAT-10). Resultados - Doze (41\%) pacientes apresentaram grau I de megaesôfago, 9 (31\%) grau II, e 8 (28\%) graus III/IV. A intensidade da disfagia não foi relacionada com o resultado do exame radiológico, com a mediana do EAT-10 de 5,5 para o grau I, 9,0 para o grau II, e 5,5 para os graus III/IV $(P>0,25)$. Engasgo (14\%), regurgitação (21\%), queixa vocal (21\%), perda de peso $(17 \%)$, e odinofagia (17\%) não foram relacionados ao grau de megaesôfago. Houve relação entre alteração vocal e odinofagia com o tempo que os pacientes tinham disfagia. Houve relação entre frequência de sintomas e valores do EAT-10 com a duração da disfagia. Conclusão - Quanto mais longo o tempo que o paciente tem disfagia maior a frequência de sintomas referidos pelos pacientes. Não há relação entre graus de megaesôfago com os sintomas e a intensidade da disfagia.

Palavras-chave - Doença de Chagas, acalasia esofágica, transtornos da deglutição, doenças do esôfago, tripanossomíase.

\section{REFERENCES}

1. Lidani KCF, Andrade FA, Bavia L, Damasceno FS, Beltrame MH, Messias-Reason IJ, et al. Chagas' disease: from discovery to a worldwide health problem. Front Public Health. 2019;7:166. doi: 10.3389/fpubh.2019.00166.

2. Roure S, Valerio L, Vallès X, Morales B, Garcia Diaz MI, Pedro-Botet ML, Serra $\mathrm{J}$. Oesophageal motility disorders in infected immigrants with Chagas disease in a non-endemic European area. United European Gastroenterol J. 2016;4:614-20.

3. Marin-Neto JA, Cunha-Neto E, Maciel BC, Simões MV. Pathogenesis of chronic Chagas heart disease. Circulation. 2007;115:1109-23.

4. Oliveira RB, Troncon LEA, Dantas RO, Meneghelli UG. Gastrointestinal manifestations of Chagas' disease. Am J Gastroenterol. 1998;93:884-9.

5. Matsuda NM, Miller SM, Évora PRB. The chronic gastrointestinal manifestations of Chagas' disease. Clinics (São Paulo). 2009;64:1219-24.

6. Dantas RO. The pharyngo-esophageal transition zone in Chagas' disease. Clin Gastroenterol Int. 2020;2:20-3.

7. Santos CM, Cassiani RA, Dantas RO. Videofluoroscopic evaluation of swallowing in Chagas' disease. Dysphagia. 2011;26:361-5.

8. Cabral DMG, Abrahão Junior LJ, Marques CHD, Pereira BB, Pedrosa RC. Oropharyngeal dysphagia in patients with chronic Chagas disease: phonoaudiological, videofluoroscopic, and manometric evauations. Acta Fisiatr. 2015;22:24-9

9. Belafsky PC, Mouadeb DA, Rees CJ, Pryor JC, Postma GN, Allen J, et al. Validity and reliability of the Eating Assessment Tool (EAT-10). Ann Otol Rhinol Laryngol. 2008;117:919-24.

10. Gonçalves MIR, Remaili CB, Behlau M. Cross-cultural adaptation of the Brazilian version of the Eating Assessment Tool EAT-10. CoDAS. 2013;25:601-4.

11. Rezende JM, Lauar KL, Oliveira AR. Aspéctos clínicos e radiológicos da aperistalsis do esôfago. Rev Bras Gastroenterol. 1960;12:247-62.
12. Abud TG, Abud LG, Vilar VS, Szejnfeld D, Reibscheid S. Radiologic findings in megaesophagus secondary to Chagas' disease: chest X-ray and esophagogram. Radiol Bras. 2016;49:358-62.

13. Vaz MGM, Rezende JM, Ximenez CA, Luquetti AO. Correlação entre a sintomatologia e a evolução do megaesôfago. Rev Goiana Med. 1995;41:1-15.

14. Koenker R, Bassett G. Regression quantiles. Econometrica. 1978;46:33-50.

15. Meneghelli UG, Peria FM, Darezzo FMR, Almeida FH, Rodrigues CM, Aprile LRO, et al. Clinical, radiographic and manometric evolution of esophageal involvement by Chagas' disease. Dysphagia. 2005;20:40-5.

16. Köberle F. Chagas' disease and Chagas' syndrome: The pathology of American trypanosomiasis. Adv Parasitol. 1968;6:63-116.

17. Sanchez-Lermen RLP, Dick E, Salas JAP, Fontes CJF. Sintomas do trato digestivo superior e distúrbios motores do esôfago em pacientes portadores da forma indeterminada da doença de Chagas crônica. Rev Soc Bras Med Trop. 2007;40:197-203.

18. Alves LR, Soares EG, Aprile LRO, Elias Junior J, Bras PBV, Baddini-Martinez J. Chlorophyllin-stained macrophages as markers of pulmonary aspiration. Am J Respir Crit Care. 2013;188:1470-2.

19. Santos CM, Cassiani RA, Dantas RO. Clinical evaluation of swallowing in Chagas' disease. Rev Soc Bras Fono. 2011;16:215-20.

20. Koidou I, Kollias N, Sdravou K, Grouios G. Dysphagia: a short review of the current state. Edu Gerontol. 2013;39:812-927.

21. Batista AO, Nascimento WV, Cassiani RA, Silva ACV, Alves LMT, Alves DC, et al. Prevalence of non-obstructive dysphagia in patients with heartburn and regurgitation. Clinics (São Paulo). 2020;75:e1556.

22. Namasivayam-MacDonald AM, Barbon CEA, Steele CM. A review of swallowing timing in the elderly. Physiol Behav. 2018;184:12-26. 